УДК $81 ` 23$

DOI https://doi.org/10.26661/2414-1135-2021-84-30

\title{
ДЕФІНІЦІЇ ПОНЯТТЯ «ДІАГНОСТИКА» НА ТЛІ СУМІЖНИХ ТЕРМІНІВ
}

\author{
Решетник О. А. \\ завідувач аспірантури, \\ здобувач ступеня вищої освіти доктора філософії \\ кафедри германської і фіно-угорської філології \\ імені професора Г. Г. Почепчова \\ Київський наиіональний лінгвістичний університет \\ вул. Велика Васильківська, 73, Київ, Україна \\ orcid.org/0000-0002-2696-4823 \\ olga.reshetnyk@knlu.edu.ua
}

Ключові слова: діагностика, вимірювання, параметризація, корпусна діагностика,

експериментальна діагностика.
Від діагностики поточного стану проблеми залежить опрацювання заходів і процедур, спрямованих на поліпшення розуміння проблеми й імплементацію практичних заходів іï розв'язання. Метою статті $\epsilon$ визначення сутності поняття «діагностика» на тлі суміжних термінів, що передбачає аналіз зазначених понять у різних галузях знань (діагностика у філософському розумінні, технічна, медична, економічна, психологічна, педагогічна, лінгвістична діагностика), окреслення параметрів, які розкривають зміст поняття «діагностика». У статті розкриті перспективи дослідження нової для психолінгвістики корпусно-експериментальної діагностичної процедури.

Поняття «діагностика» в міждисциплінарному вимірі позначає теорію, принципи, підходи, методи й інструменти розпізнання, оцінки й вимірювання об’єктів дослідження, визначення причин і динаміки їх змін iз метою подальшого прогнозу й надання рекомендацій щодо покращення актуального стану. Продукція кваліфікованої діагностики дозволяє скласти актуальну картину стану досліджуваного об'єкта, визначити процеси, які відбуваються 3 об’єктом, виміряти їх інтенсивність, установити направленість, окреслити причинно-наслідкові й функційні зв'язки з навколишнім середовищем. Діагностика завжди опосередкована методологічним підгрунтям i діагностичним інструментарієм i використовує прийняту для певної галузі термінологію.

Перспективним напрямом дослідження в психолінгвістиці є корпусноекспериментальна діагностика (А.В. Корольова, О.О. Черхава, Н.М. Бобер, Я.В. Капранов), яка дозволяє сформувати науковий об'єм певного поняття за допомогою відбору інформації в корпусі й опрацювати іï експериментальним шляхом завдяки комплексу методів i методик. Підгрунтям корпусно-експериментальної діагностики як нової методологічної процедури й методу наукового пізнання стали напрацювання в галузі корпусної лінгвістики, дослідження якої зосереджені на вивченні питань відбору й способів представлення інформації в корпусі для отримання повного уявлення щодо досліджуваного явища й певної мови в цілому. 


\title{
DEFINITIONS OF DIAGNOSTICS NOTION AND RELATED TERMS
}

\author{
Reshetnyk O. A. \\ Head of the Department of Postgraduate Study, \\ Ph.D. Applicant at the Professor G. G. Pocheptsov Department \\ of German and Finno-Ugric Philology \\ Kyiv National Linguistic University \\ Velyka Vasylkivska str., 73, Kyiv, Ukraine \\ orcid.org/0000-0002-2696-4823 \\ olga.reshetnyk@knlu.edu.ua
}

Key words: diagnostics, measurement, parameterization, corpus diagnostics, experimental diagnostics.

\begin{abstract}
Diagnostics of the problem current state contributes to the development of measures and procedures aimed at improving the understanding of the problem essence and the implementation of practical ways to solve it. The article aims at defining the concept of diagnostics compared to the related terms, which involves these concepts' analysis in different fields of study (diagnostics in the philosophical sense, technical, medical, economic, psychological, pedagogical, linguistic diagnostics), defining parameters that reveal the meaning of the diagnostics concept. The article identifies the concept and prospects for a corpus-experimental diagnostic procedure study, considered a new branch of psycholinguistics.

The notion of diagnostics in the interdisciplinary dimension implies a theory, principles, approaches, methods, and tools for detecting, recognizing, evaluating, and measuring research objects, determining the causes and dynamics of their changes to further predict and provide recommendations for improvement. The product of qualified diagnostics allows to compile a topical picture of the state or capability of the research object, determine the processes that occur with it, measure their intensity, determine the direction, identify causal and functional relationships with the environment. Diagnostics is reinforced by the methodological basis and diagnostic tools and uses accepted terminology for a particular field of study.

A promising area of research in psycholinguistics is corpus-experimental diagnostics (A. Korolyova, O. Cherkhava, N. Bober, Ya. Kapranov, N. Stefanova). It is aimed at creating the scientific volume of a research concept by selecting information in corpus and experimentally processing it via a set of methods and techniques with their specific toolkit. The basis of the corpusexperimental diagnostics as a new methodological procedure is composed of works in corpus linguistics, focused mainly on the study of selection and methods of presenting information in the corpus to obtain a complete picture of the phenomenon and language in general.
\end{abstract}

Постановка проблеми. У сучасних умовах стрімкого науково-технічного прогресу необхідність адаптації до мінливого середовища, толерантності до невизначеності в епоху радикальних змін стає надперспективною. Більшість досліджень, зокрема в галузях суспільних і гуманітарних наук, прикладним аспектом має розроблення та впровадження методів, методик, технік і технологій удосконалення функціонування певної системи. Проте це неможливо без попередньої якісної діагностики. Практично не існує сфери життєдіяльності людини й суспільства, в якій не виникає потреби в діагностиці. 3 розвитком наукової думки питання початкового встановлення «діагнозу» й пошук механізмів, здатних забезпечити розв'язання проблеми 3 найефективнішим результатом, все більш актуалізується. Від діагностики поточного стану проблеми залежить опрацювання заходів і процедур, спрямованих на поліпшення розуміння проблеми й імплементацію практичних заходів ії розв’язання [1].

Разом із тим не вирішеним залишається питання сутності поняття «діагностика» в міждисциплінарному дискурсі, його всебічне осмислення на тлі суміжних термінів і понять, оскільки більшість визначень терміну й переважно прикладний характер досліджень фахівців галузевих діагностик (психологічної, лінгвістичної, 
медичної, технічної, економічної тощо) не може бути інтегрованим у рівень міждисциплінарного аналізу [1].

Дослідження спрямоване на визначення ключових параметрів, які формують цілісне розуміння поняття «діагностика» на тлі суміжних термінів, і перспективи нового для психолінгвістики корпусно-експериментального підходу й діагностичної процедури.

Методологічну основу роботи склали напрацювання фахівців різних галузей знань. Це передусім практики психологічної, психолінгвістичної, філологічної наук: Б.Г. Ананьєв, Д. Байбер, М.Я. Басов, С.Н. Бук, Л.Ф. Бурлачук, О.І. Ванівська, К.М. Гуревич, Н.П. Дарчук, О.М. Демська-Кульчицька, С.В. Засєкін, С.Я. Зейгарник, Є.А. Карпіловська, Дж. Кесс, А.В. Корольова, О.М. Леонтьєв, О.О. Леонтьєв, А.Р. Лурія, Т.Б. Маслова, О.О. Селіванова, Дж. Сінклер, О.І. Смашнюк, В.Ф. Старко, В.В. Столін, В. Тойберт, О.Ю. Плахотнікова, В.О. Плунгян, Г.Г. Почепцов, О.О. Черхава, М.О. Шведова, У.Н. Френсіс та інші.

\section{Мета й завдання статті.}

Мета статті - розглянути дефініції поняття «діагностика» й суміжних із ним понять у сучасному наукознавстві.

Завдання:

- проаналізувати дефініції поняття «діагностика», подані в енциклопедичних і / або лексикографічних (тлумачних) джерелах, а також виокремити його синонімічні поняття;

- представити дефініції поняття «діагностика» в контексті міждисциплінарної парадигми;

- визначити комплекс специфічних ознак, які розкривають зміст поняття «діагностика»;

- надати ключові ознаки й характеристики, які розкривають зміст поняття «діагностика»в психолінгвістиці.

Предмет та об'єкт дослідження. Об'єктом дослідження $є$ поняття «діагностика». Предметом дослідження вбачаємо поняття «діагностика» в міждисциплінарному вимірі на тлі суміжних термінів.

Виклад основного матеріалу дослідження.

Опрацювання енциклопедичних i лексикографічних (тлумачних) джерел дозволяє переконатися в тому, що поняття «діагностика» належить до проблематики медичного дискурсу. У «Словнику української мови» термін витлумачується ширше для медичної галузі: «розділ медицини, який вивчає ознаки хвороб, методи й принципи дослідження організму для встановлення діагнозу» [2, с. 293], а в «Большом энциклопедическом словаре» - вужче: «вчення про методи й принципи розпізнавання хвороб і постановки діагнозу; процес постановки діагнозу» [3].
У результаті аналізу термінів словників-тезаурусів на предмет визначення поняття «діагностика» маємо таке узагальнене уявлення про згаданий термін: це процес визначення стану або здатності компонента [4], виявлення того, що не так $з$ об'єктом дослідження [5] на основі поєднання ознак і симптомів (параметрів), комплекс методів або систем для виявлення причини проблеми [6].

Термін «діагностика» походить із грецької мови й дослівно перекладається як «розпіз-

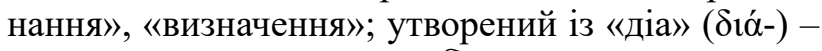
через, наскрізь і гнозис ( $\gamma \nu$ $\sigma 1 \varsigma)$ - пізнання, наука, ясність [7, с. 82]. У найпоширенішому тлумаченні під діагностикою розуміють галузь знань, що вивчає теорію та методи організації процесів встановлення діагнозу, а також принципи побудови засобів діагностування [8]. Діагностика покликана розробляти теорію, принципи й інструменти оцінки й вимірювання досліджуваних об'єктів із метою подальшого підвищення їх ефективності, надійності й ресурсу. Діагностика - це вчення про способи встановлення діагнозу (словник Ожегова, словник Ушакова, словник Єфремової), мистецтво або практика діагностування (словник MerriamWebster). Діагностика розглядається як процедура оцінки того, наскільки модель відрізняється від очікуваних патернів і припущень [9, с. 309].

Загальнонауковий термін «діагностика» може бути розкритий, спираючись на різні класифікації: за галуззю знань (медична, психологічна, професійна, лінгвістична, технічна, економічна тощо); за організаційною формою проведення (внутрішня, зовнішня; контактна, безконтактна); за обсягом дослідження (повна (комплексна), неповна (тематична, діагностика окремих систем)); за методикою дослідження (експериментальна, корпусна; експрес-діагностика, фундаментальна діагностика; інструментальна; лабораторна; диференційна діагностика, діагностична оцінка, діагностичне тестування; скринінгова); за часовою ознакою (попередня (прогнозна), поточна (оперативна), наступна (ретроспективна)); постійна й періодична; стратегічна; за змістом процесу (ретроспективна, перспективна; скринінгова); за цільовою спрямованістю (загальносистемна, прикладна); за формою оцінки результатів (кількісна, якісна); за об'єктом і суб'єктом діагностування.

Порівняння та аналіз терміну «діагностика» в різних галузях знань дозволяє виокремити ряд спільних параметрів, які складають сутність поняття. Найбільш загальнонауковий підхід до визначення зазначеного поняття представлено у філософії.

Діагностика у філософії визначається як різновид пізнавальної діяльності (наукового пізнання), 
спрямованої на розпізнавання певного знання одиничної сутності - заданого об'єкта, процесу або ситуації (передбачається вже наявне знання про об'єкт або про однотипні з ним об'єкти - діагностичний образ має на увазі апріорне знання, яке передує діагностичному пошуку й каналізує (направляє) його, зумовлюючи тим самим спектр можливих результатів пошуку). Розпізнавання полягає у формуванні когнітивного образу досліджуваного об'єкта: образу індивідуальності - в індивідуалізуючій діагностиці, і типологічного образу - в типологізуючій діагностиці. Формувальним компонентом діагностики є процес та алгоритм ідентифікації. У всіх діагностичних практиках операції ототожнення передує виявлення ознак, визначення яких проводиться фактологічними методами дослідження. У медицині це фізичні методи, лабораторні, інструментальні; в соціології - інтерв'ю, анкетне опитування, включене спостереження, контент-аналіз тощо; у лінгвістиці - анкетування, корпусні технології діагностики. Функціональне призначення діагностики полягає в описі, поясненні й оцінці поточного стану іiі об'єктів, виявленні причин і динаміки їх зміни, що своєю чергою покладає основу прогнозам і прийняттю рішень [1].

Разом із тим деякі з ключових параметрів концепту «діагностика» розкриваються в дефініціях поняття в різних галузях знань. Зокрема, технічна діагностика являє собою комплекс робіт за контролем технічного стану, а також галузь знань, що досліджує технічний стан і наявність дефектів в об'єктів діагностування (машин, пристроїв, елементів), прояв безлічі їх технічних станів, розробляє методи й засоби їх визначення та локалізації, а також принципи побудови й організацію використання систем діагностування, спрямованих на підвищення надійності й ресурсу технічних систем [10].

На відміну від технічної, під медичною діагностикою розуміють комплекс заходів, спрямованих на визначення причини захворювання пацієнта, його актуального стану й установлення діагнозу (висновок про сутність захворювання), вираженого в прийнятій медичній термінології [11].

Для сфери гуманітарних i суспільних наук дещо зміщуються акценти об'єкта дослідження. Економічна діагностика передбачає детальне й комплексне дослідження об'єкта 3 метою отримання максимально достовірної інформації про поточний стан і перспективи розвитку підприємства й застосовується в процесі управління підприємством безперервно, оскільки дає змогу виявляти нові тенденції, які потребують внесення змін в оперативне управління фінансовою та господарською діяльністю [12, с. 242; 13]. Метою такої діагностики є встановлення діагнозу об' єкта дослідження та надання висновку про його стан. Основні ж завдання полягають у визначенні заходів, спрямованих на налагодження роботи всіх складових елементів системи й способів їх реалізації [13].

3 організаційного погляду діагностика - це система методів, прийомів і методик проведення досліджень для визначення цілей функціонування суб’єкта господарювання, способів іiі досягнення, виявлення проблем і вибору варіантів їхнього розв'язання [14].

Педагогічна діагностика покликана з'ясувати умови й обставини, в яких формуються знання, уміння та навички учнів, умови розвитку й виховання особистості учня в процесі опанування ним знань і вмінь. Результати діагностики слугують основою для внесення необхідних корективів у навчальний процес, прийняття рішень про вдосконалення його змісту, методів і форм організації, управління навчально-пізнавальною діяльністю здобувачів освіти тощо [15, с. 358]. Важливою особливістю діагностики є прогностичний характер їі висновків. Прогноз потрібний для того, щоб внести необхідні корекції розвитку учня: підсилити бажані й нейтралізувати небажані тенденції. У такому розумінні діагностика є основою індивідуального підходу до вихованця.

Особливістю психодіагностики є розроблення методів розпізнання, вимірювання та інтерпретації індивідуально-психологічних особливостей особистості. Предметом психодіагностики стають вимірювані індивідуально-психологічні особливості особистості, де результатом пізнання $\epsilon$ вже заміряні особливості (у кількісних величинах названі особливості, що становлять основу психологічного діагнозу) [16, с. 87]. Основним інструментарієм психодіагностики є стандартизовані методики, що мають такі основні психометричні характеристики, як надійність, валідність, стандартні статистичні норми $[17$, с. 240$]$. Психологічна діагностика передбачає оцінку того, наскільки модель відрізняється від очікуваної моделі. Наприклад, психологічна діагностика може виявити, наскільки набір даних відхиляється від припущень про нормальність, лінійність та однорідність дисперсії, і показати криволінійні й нерівномірні відхилення між рівнями іншої змінної відповідно [9, с. 309]. Психологічна професійна діагностика передбачає оцінку потенційних професійних здібностей, конкретних індивідуально-психологічних властивостей особистості, необхідних для виконання певних видів професійної діяльності [9, с. 315].

Міждисциплінарна психолінгвістична діагностика може мати на меті виявлення особистісних рис носія мови на основі аналізу його 
мовлення, окреслити динаміку когнітивного, емотивного, асоціативного, семантичного наповнення свідомості носія мови залежно від різних зовнішніх і внутрішніх факторів і запропонувати методи корекції. Якщо психолінгвістика «вивчає, 3 одного боку, співвідношення особистості зі структурою та функціями мовленнєвої діяльності, а 3 іншого, - особистості з мовою як основною складовою частиною образу світу людини», предметом дослідження мають бути «закономірності психічних явищ і механізмів, які зумовлюють функціонування мови й мовлення», а метою «опис і пояснення особливостей функціонування мови й мовлення як психічних феноменів з урахуванням взаємодії зовнішніх і внутрішніх чинників соціально-культурної діяльності особистості» $[18$, с. 8,11$]$, то можемо визначити ключові ознаки, які розкривають зміст поняття «діагностика» в психолінгвістиці. Психолінгвістична діагностика:

1) спрямована на розпізнавання особливостей мовної особистості як носія національно-культурного простору, відтвореного в мовній картині світу;

2) передбачає визначену методологію на філософському, загальнонауковому, конкретнонауковому рівнях і рівні методів дослідження (набір методів, методик і технік дослідження, як-от психолінгвістичні методи, містить метод контент- й інтент-аналізу, метод семантичного диференціала, асоціативний експеримент, психографологічний метод, методи когнітивного картування тощо);

3) застосовується 3 метою побудови семантичних просторів реципієнтів і моделювання типових реакцій мовців задля прогнозування їх поведінки в різних життєвих контекстах.

Дослідження категорії «діагностика» набуває особливого значення з розвитком корпусної лінгвістики як нового напряму психолінгвістичних досліджень. Гуманітарна наука збагатилася дослідженнями, зосередженими на мовних одиницях у всіх їх зв'язках і відношеннях (багатовимірності) [19, с. 34], вивченні питань відбору й способів представлення інформації в корпусі, використання корпусу текстів для розв'язання лінгвістичних завдань різного характеру, зокрема отримання повного уявлення щодо досліджуваного явища й певної мови в цілому, завдяки ефективній обробці великих об'ємів текстів і здійснення вибірки даних через систему оперативного пошуку інформації [20, с. 24]. У такому ключі можемо визначити такий напрям діагностики, як корпусна діагностика, яка покликана забезпечити пошук у мультимовних корпусах ключових слів відповідно до об'єкта дослідження та дозволить сформувати науковий об'єм певного поняття, укласти його в лінгвістичну базу даних. Високої актуальності набувають прикладні корпусні дослідження, спрямовані на формування бази лінгвістичних дескрипторів досліджуваного об'єкта (наприклад, дослідження Е. Семіно, Е. Харді й Дж. Закревської щодо застосування корпусної лінгвістики під час діагностування больового синдрому, 2016 р.; дослідження Ф. Брін-Генрі щодо використання корпусного аналізу в спеціалізованій парамедичній мові, 2014 р. тощо).

Проведення психолінгвістичного експерименту, який передбачає застосування комплексу методів і методик з їх інструментарієм і полягає в організації цілеспрямованого дослідження мовленнєвої діяльності й засобів іiі реалізації, може бути тією діагностичною процедурою, яка здатна забезпечити подальший аналіз та інтерпретацію отриманих даних і надання рекомендацій щодо покращення стану досліджуваного об’єкта.

Повний комплекс зазначених процедур, якому передує розробка корпусно-експериментального підходу, безперечно, є перспективним напрямом дослідження, основи якому покладені в працях учнів наукової школи професора А.В. Корольової О.О. Черхави, Н.М. Бобер, Я.В. Капранова.

3 аналізу категорії «діагностика» видно, що вона є ключовою для будь-якої галузі знань із прикладною спрямованістю. Важливо виокремити, в якому контексті вчені розглядають поняття, 3 якими термінами подекуди його ототожнюють та яке з визначень забезпечує найширше концептуальне розуміння категорії.

Діагностика може розглядатися як фіксація окремих реакцій, як вимірювання якісних і кількісних показників, як оцінка (оцінювання) та як параметризація.

Поняття «діагностика» ширше, ніж поняття «вимірювання». Вимірювання проводиться 3 метою констатації стану, є процесом визначення числового значення вимірюваної величини. Параметризація передбачає виокремлення та визначення основних, істотних параметрів досліджуваного явища й розрахунок їхніх, зокрема чисельних, значень у системному аналізі [21]. Оцінка (оцінювання) є причиною глибшого вивчення протікання певного процесу, визначення шляхів його вдосконалення на основі знання про способи й умови взаємодії його компонентів [15, с. 358].

Діагностика в ширшому розумінні включає у свою структуру всі вищезазначені поняття та передбачає насамперед комплекс засадничих принципів, підходів, методів, технологій i процедур, які дозволяють оцінити, описати й інтерпретувати дані про поточний стан об'єкта дослідження, виявити причини й динаміку змін, спрогнозувати подальші перспективи й напрям розвитку об’єкта дослідження.

У результаті аналізу й порівняння дефініцій поняття «діагностика» в різних галузях знань (технічна, медична, економічна, психологічна, 
лінгвістична) варто виділити ключові позиції, які формують цілісне розуміння поняття, визначають комплекс специфікуючих ознак i розкривають зміст такої діяльності, а саме:

1) визначення діагностики як методів, засобів i процедур розпізнавання / встановлення / оцінки / вимірювання (параметризації) актуального стану явища;

2) інструментальний компонент (методологія, методи й засоби, якими можуть бути виявлені ідентифікаційні ознаки об'єкта дослідження);

3) прогноз / забезпечення ефективності роботи й надання рекомендацій щодо покращення актуального стану;

4) використання прийнятої для певної галузі знань термінології.

Кваліфікована діагностика та іï продукція дозволяє скласти актуальну картину стану досліджуваного об'єкта, визначити процеси, які відбуваються 3 об'єктом, виміряти їх інтенсивність, окреслити направленість, розглянути причинно-наслідкові й функційні зв'язки 3 навколишнім середовищем із метою покращення актуального стану.

Висновки й перспективи подальших розробок.

Діагностика надає змогу отримати емпіричне й методологічне знання про об'єкт дослідження та його маніфестації. Точна оцінка, параметризація та подальша вдосконалена типологізація та алгоритмізація об'єктів дослідження, будь то станів, психологічних чи фізичних особливостей тощо, безпосередньо впливає на якість життєдіяльності. Поняття «діагностика»») в загальнонауковому розумінні позначає теорію, принципи й інструменти оцінки й вимірювання об'єктів дослідження 3 метою подальшого підвищення ефективності життєдіяльності об'єкта. У результаті аналізу й порівняння дефініцій поняття «діагностика» в різних галузях знань було визначено низку параметрів, які формують цілісне розуміння. Діагностика в міждисциплінарному вимірі передбачає комплекс засадничих принципів, підходів, методів, технологій і процедур, які дозволяють виміряти, параметризувати, оцінити й інтерпретувати дані про поточний стан об'єкта дослідження, виявити причини й динаміку змін, спрогнозувати подальші перспективи.

Перспективним напрямом дослідження в психолінгвістиці стає корпусно-експериментальна діагностика, яка дозволяє сформувати науковий об'єм певного поняття за допомогою відбору інформації в корпусі й опрацювати ії експериментальним шляхом завдяки комплексу методів і методик з їх інструментарієм.

\section{ЛITЕРАТУРА}

1. Кротков Е.А. Диагностика как универсальная форма научного познания (эпистемологический анализ). Вопросы философии. 2014. URL: $\quad$ http://vphil.ru/index.php?option=com content\&task=view\&id=934 (дата звернення: 30.09.2021).

2. Словник української мови : в 11 т. / за ред. І.К. Білодід ; Ін-т мовознавства ім. О.О. Потебні. Київ :. Наукова думка, 1971. Т. 2. 550 c. URL: http://irbis-nbuv.gov.ua/ulib/item/ UKR0001603 (дата звернення: 06.10.2021).

3. Большой энциклопедический словарь. URL: https://gufo.me/dict/bes/ДИАГНОСТИКА (дата звернення: 02.10.2021).

4. Оксфордський багатомовний онлайн-словник Glosbe. URL: https://uk.glosbe.com/en/uk/ Oxford (дата звернення: 06.10.2021).

5. Longman Dictionary of Contemporary English. URL: https://www.ldoceonline.com/dictionary (дата звернення: 04.10.2021).

6. Cambridge Advanced Learner's Dictionary \& Thesaurus. URL: https://dictionary.cambridge.org/dictionary/english/ (дата звернення: 04.10.2021).

7. Етимологічний словник української мови : в 7 т. / за ред. : О.С. Мельничук, В.Т. Коломієць, О.Б. Ткаченко ; Ін-т мовознавства ім. О.О. Потебні. Київ : Наукова думка, 1985. Т. 2. 572 с.

8. Словник української мови online. Томи 1-11. URL: $\quad$ services.ulif.org.ua/expl/Entry/index? wordid=22477\&page=767 (дата звернення: 07.10.2021).

9. APA dictionary of psychology / Ed. G.R. VandenBos. Washington, DC, USA : American Psychological Association, 2015. $1204 \mathrm{p}$.

10. Технічна діагностика : Атестаційний центр неруйнівного контролю при Інституті електрозварювання ім. Є.O. Патона HAHУ URL: http:// acnk.kiev.ua/poslugi/tehnichna-diagnostika/.

11. The free dictionary by Farlex. Medical Dictionary. 2009. URL: https://medical-dictionary. thefreedictionary.com/medical+diagnosis (дата звернення: 26.09.2021).

12. Масленніков А.Ю., Когут Р.В. Діагностика в системі управління економікою підприємства. Науковий вісник НЛТУ. Львів, 2012. № 22.7. C. 240-243.

13. Ткаченко А.М. Управління економічною діагностикою будівельного підприємства як основа його ризик-менеджменту. Ефективна економіка. Дніпро, 2012. № 6. URL: http:// www.economy.nayka.com.ua/?op=1\&z=1756 (дата звернення: 21.09.2021).

14. Борисов А.Б. Большой экономический словарь. Москва : Книжный мир, 2000. 895 с.

15. Мойсеюк Н.Є. Педагогіка : навчальний посібник. 5-те вид., доп. і перероб. Київ : Саміткнига, 2007. $656 \mathrm{c.}$

16. Бурлачук Л.Ф. Психодіагностика особистості: понятійний апарат та методи дослідження. Психологія і суспільство. Тернопіль, 2014. № 4. C. $85-103$. 
17. Психологічний словник / за заг. ред. Н.А. Побірченко ; уклад. В.В. Синявський, О.П. Сергєєнкова. Київ, 2007. 336 с.

18. Засєкіна Л.В., Засєкн С.В. Психолінгвістична діагностика : навчальний посібник. Луцьк : PВВ «Вежа» Волин. нац. ун-ту ім. Лесі Українки, 2008. 188 с.

19. Лучик А.А., Остапова I.B. Синтагматична параметризація еквівалентів слова у парадигмі корпусної лінгвістики. Human. Computer. Communication : матеріали міжнародної наукової конференції, м. Львів, 20-22 вересня 2017 р. Львів, 2017. С. 33-37.

20. Бобер Н.М. Метричне профілювання семантики фразово-дієслівних емотивів у британському національному корпусі : дис. ... канд. філол. наук : 10.02.21 ; Національний педагогічний університет імені М.П. Драгоманова. Київ, 2020. 227 с.

21. Словник української мови та культури. URL: https://slovnyk.ua/index.php?swrd=параметризація (дата звернення: 26.09.2021).

\section{REFERENCES}

1. Krotkov, Ye.A. (2014). Dignostika kak universalnaya forma nauchnogo poznaniya (epistemologicheskiy analiz) [Diagnosis as a universal form of scientific knowledge (epistemological analysis)] Voprosyi filosofii. URL: http://vphil.ru/index.php? option=com content\&task=view\&id=934 [in Russian].

2. Slovnyk ukrainskoi movy [Ukrainian language dictionary]. (1971). (Vol. 2). URL: http:// irbis-nbuv.gov.ua/ulib/item/UKR0001603 [in Ukrainian].

3. Bolshoy entsiklopedicheskiy slovar. URL: https:// gufo.me/gufo.me/dict/bes/ДИАГНОСТИКА [in Russian].

4. Oksfordskyi bahatomovnyi onlain-slovnyk Glosbe [Oxford Multilingual Online Dictionary Glosbe]. URL: https://uk.glosbe.com/en/uk/Oxford [in Ukrainian].

5. Longman Dictionary of Contemporary English. URL: https://www.ldoceonline.com/dictionary [in English].

6. Cambridge Advanced Learner's Dictionary \& Thesaurus. URL: https://dictionary.cambridge. org/dictionary/english/ [in English].

7. Melnychuk, O.S., Kolomiiets, V.T., Tkacenko, O.B. (Eds.) (1985). Etymolohichnyi slovnyk ukrainskoi movy [Etymological dictionary of the Ukrainian language]. (Vol. 2). Kyiv: Naukova dumka [in Ukrainian].

8. Slovnyk ukrainskoi movy online [Dictionary of the Ukrainian language online]. (Vols. 1-11). URL: services.ulif.org.ua/expl/ Entry/index? wordid $=22477$ \&page $=767$.

9. VandenBos, G.R. (Ed.) (2015). APA dictionary of psychology. Washington, DC, USA: American Psychological Association [in English].
10. Tekhnichna diahnostyka. Atestatsiinyi tsentr neruinivnoho kontroliu pry Instytuti elektrozvariuvannia im. Ye.O. Paton NANU [Technical diagnostics. Certification center of non-destructive testing at the Institute of Electric Welding. Named after Ye.O. Paton NASU]. URL: http://acnk.kiev.ua/poslugi/tehnichnadiagnostika/.

11. The free dictionary by Farlex. Medical Dictionary. (2009). URL: https://medical-dictionary. thefreedictionary.com/medical+diagnosis.

12. Maslennikov, A.Yu., Kohut, R.V. (2012). Diahnostyka v systemi upravlinnia ekonomikoiu pidpryiemstva [Diagnostics in the management system of the economy of the enterprise] Naukovyi visnyk NLTU, № 22.7 [in Ukrainian].

13. Tkachenko, A.M. (2012). Upravlinnia ekonomichnoiu diahnostykoiu budivelnoho pidpryiemstva, yak osnova yoho ryzyk-menedzhmentu [The building enterprise's economic diagnostics as a foundation of its risk-management]. Efektyvna ekonomika, № 6. URL: http://www.economy.nayka.com.ua/? $\mathrm{op}=1 \& \mathrm{z}=1756$ [in Ukrainian].

14. Borysov, A.B. (Ed.) (2000). Bolshoy ekonomicheskiy slovar [Big Dictionary of Economics] M. Knizhnyiy mir [in Russian].

15. Moiseiuk, N.Ye. (2007). Pedahohika [Pedagogy]. Kyiv: Samit-knyha [in Ukrainian].

16. Burlachuk, L.F. (2014). Psykhodiahnostyka osobystosti: poniatiinyi aparat ta metody doslidzhennia [Personality psychodiagnostics: concepts and research methods]. In Psykholohiia i suspilstvo [Psychology and society] (pp. 85-103). Ternopil [in Ukrainian].

17. Pobirchenko, N.A. (Ed.) (2007). Psykholohichnyi slovnyk [Psychological dictionary]. Kyiv [in Ukrainian].

18. Zasiekina, L.V., Zasiekn, S.V. (2008). Psykholinhvistychna diahnostyka [Psycholinguistic diagnostics]. Lutsk : RVV "Vezha". [in Ukrainian].

19. Luchyk, A., Ostapova, I. (2017). Syntahmatychna parametryzatsiia ekvivalentiv slova u paradyhmi korpusnoi linhvistyky [Syntagmatic parameterization of word equivalents in the paradigm of corpus linguistics], Human. Computer. Communication, materialy Mizhnarodnoi nauk. konf. [Human. Computer. Communication, Proceedings of International Scientific Conference]. Lviv [in Ukrainian].

20. Bober, N.M. (2020) Metrychne profiliuvannia semantyky frazovo-diieslivnykh emotyviv $u$ brytanskomu natsionalnomu korpusi [Matrix Profiling of the Semantics of Phrasal Emotive verbs in the British National Corpus]. Candidate's thesis). National Pedagogical Dragomanov University, Ministry of Education and Science of Ukraine, Kyiv [in Ukrainian].

21. Slovnyk ukrainskoi movy ta kultury [Dictionary of Ukrainian language and culture]. URL: https:// slovnyk.ua/index.php?swrd=параметризація [in Ukrainian]. 